\title{
Investigation of the Optimum Pretreatment Conditions for the Knitted Fabric Derived from PLA/Cotton Blend
}

\author{
Issara Na Phatthalung, Porntip Sae-be, Jantip Suesat, Potjanart Suwanruji, and Nantaporn Soonsinpai
}

\begin{abstract}
The pretreatment processes prior to dyeing which were the scouring and bleaching, for the knitted fabric of PLA/cotton blend were studied comparing with the $100 \%$ cotton and PLA fabrics. These two pretreatment processes were studied in a sequence (scouring followed by $\mathrm{H}_{2} \mathrm{O}_{2}$ bleaching) and altogether in the one-bath process. The scouring process of the blended fabric was compared when the different scouring agents were employed ( $\mathrm{NaOH}, \mathrm{Na}_{2} \mathrm{CO}_{3}$ and pectinase enzyme). The two-bath and one-bath scouring/bleaching processes had a signified effect on the strength of the fabrics because the pretreatment processes typically used for cotton are in the alkaline condition which can deteriorate the PLA fiber. Therefore, the pretreatment conditions for the PLA/cotton blended fabric needed to be optimized to avoid fiber damage. From the research, it was observed that the pretreatments for the blended fabric, which was to enter the pale-shade dyeing, were scoured using $10 \%$ owf pectinase $\left(60^{\circ} \mathrm{C}, 60 \mathrm{~min}\right)$ as it enhanced a satisfactory water absorbency to the fabric without causing any adverse effect on the fabric strength. For deep-shade dyeing, the blended fabric should undergo the one-bath scouring/bleaching with $7 \%$ owf $\mathrm{H}_{2} \mathrm{O}_{2}\left(100^{\circ} \mathrm{C}, 60 \mathrm{~min}\right)$ which yielded a water absorbency and whiteness on the fabric to a standard level and the resulting fabric strength was highest and this one-bath pretreament was the time-saving process.
\end{abstract}

Index Terms-Pretreatment, knitted fabric, scouring, bleaching, PLA/cotton blend

\section{INTRODUCTION}

Polyester is a synthetic fiber being increasingly consumed in the textile industry every year. In 2009, its market share was as high as $80 \%$ of the synthetic fiber market and China was the chief producer [1]. Polyester fiber is a strong, light-weight fiber with a good dimensional stability and cheap price. However, the starting raw materials used for the polyester manufacturing are the petrochemicals supplied from the petroleum industry. The petroleum price is rising every year because fossil resources are limited. At the same time, the manufacturing process of polyester also produces a

Manuscript received April 25, 2012; revised May 30, 2012.

I. Na Phatthalung is with the Department of Textile Science, Faculty of Agro-Industry, Kasetsart University, Bangkok, 10900, Thailand (e-mail: Issara_5415@hotmail.co.th).

P. Sae-be is with the Department of Textile Science, Faculty of Agro-Industry, Kasetsart University, Bangkok, 10900, Thailand (corresponding author, phone: 66-2-5625065; fax: 66-2-9428663; e-mail: fagipts@ku.ac.th ).

J. Suesat is with the Department of Textile Science, Faculty of Agro-Industry, Kasetsart University, Bangkok, 10900, Thailand (e-mail: Jantip.s@ku.ac.th ).

P. Suwanruji is with the Department of Chemistry, Faculty of Science, Kasetsart University, Bangkok, 10900, Thailand (e-mail:fscipjs@ku.ac.th).

N. Soonsinpai is with the Department of Textile Science, Faculty of Agro-Industry, Kasetsart University, Bangkok, 10900, Thailand (e-mail: nookpete@hotmail.com). high- $\mathrm{CO}_{2}$ emission and the wastes generated are also difficult to dispose of. Therefore, the researches have focused on an alternative environmental-friendly fiber which has comparable properties and can be used as a substitute of the conventional polyester fiber, poly (ethylene terephthalate) (PET). In 2002, Cargill Dow Polymer LLC, a joint venture between Cargill and Dow Chemical companies opened a production plant to produce a biodegradable polyester fiber, polylactic acid (PLA), with the purpose of replacing the petroleum-based PET fiber. The different structures between PET and PLA are shown in Fig. 1 [2].

PLA fiber has been considered as a new polyester fiber for the textile industry. It possesses several desired properties for use in the production of the textiles highlighting the eco-friendliness and non-petroleum base. As PLA has relatively low thermal stability, its molecule can be degraded by thermal hydrolysis [3], [4]. The PLA fiber used in the textile industry has the melting point of about $170^{\circ} \mathrm{C}$ [5]. This makes the textiles derived from PLA fiber sensitive to heat Ironing the PLA woven fabric should be avoided as it may cause a fused fabric surface. In order to tackle this problem, it is recommended to produce the PLA fiber into the form of knitted fabric because the fabric structure is more flexible and better resistant to wrinkles than the woven counterpart, therefore, ironing is not needed or low-temperature ironing can be used. Another solution is to blend the PLA fiber with other fibers with better thermal properties e.g. cotton. Cotton, not only enhances the thermal resistance, but also reduces the cost of the fiber production as PLA fiber is expensive. The blend of PLA and cotton produces a $100 \%$ biodegradable fabric. Moreover, a strong and dimensional stable fabric with good moisture absorption can be achieved [6].

Pretreatments of the fabrics prior to the dyeing process are essential processes that help to promote the dyeability of the fabric before passing it to the coloration process. The typical pretreatment processes are singeing, desizing, scouring and bleaching. The pretreatment processes chosen for any particular fabrics vary depending on the extent of impurities present on the fiber or fabric that can affect the efficiency of the subsequent dyeing process [7]. The knitted fabric of PLA/cotton blend requires 2 important pretreatment processes which are the scouring and bleaching processes. Owing to the high content of impurity on cotton, it needs to be scoured to get rid of the natural oils, fats, waxes, and partially remove some proteins and pectin. The cotton fabric which has been through an incomplete scouring will only slightly absorb water. If it is taken to the dyeing process, the shade obtained on the fabric will be unlevel. There are two general scouring processes used in the industry. The first method is the use of alkali to remove fats and oils by means of saponification reaction. The second is the enzymatic 
scouring method in which the impurities on cotton are eliminated via hydrolysis reaction. There are several enzymes employed in the textile industry, e.g. pectinase, lipase, protease and cellulase. Selection of enzymes for scouring depends on the types of impurities to be removed and the process used. The advantage of enzymatic scouring is that the processing temperature can be reduced because most enzymatic scouring is normally performed at lower temperature and $\mathrm{pH}$ compared with alkali scouring. Furthermore, enzymes do not deteriorate cellulose structure, hence, the fiber strength is not affected [8].

The current research aimed to study the optimum pretreatment conditions viz. scouring and bleaching, to improve the water absorption capacity and whiteness of the PLA/cotton blended fabric and the effectiveness of the scouring and bleaching processes at different conditions were informed.<smiles>O=C(OCCO)c1ccc(C(=O)OOCCCOC(=O)c2ccc(C(=O)OCCCO)cc2)cc1</smiles>

(a) PET<smiles>CC(C)C(=O)O[TlH]</smiles>

(b) PLA

Fig. 1. Chemical structures of the polyester fibers

\section{MATERIALS AND METHOD}

\section{A. Materials}

The pique-knitted fabrics of the PLA/cotton blend (weight of $227 \mathrm{~g} / \mathrm{m}^{2}$ ), $100 \%$ cotton (weight $239 \mathrm{~g} / \mathrm{m}^{2}$ ) and $100 \%$ PLA (weight $213 \mathrm{~g} / \mathrm{m}^{2}$ ) were prepared from the PLA and cotton spun yarns. The PLA spun yarn was purchased from Hebei Tianlun Textile Co. Ltd., China and the cotton spun yarn was supplied by Far East Knitting \& Spinning Co., Ltd, Thailand. Dypidol 101B (a non-ionic wetting agent) and Scourzyme ${ }^{\circledR}$ L (pectinase enzyme) were supplied by Brenntag Co., Ltd, Thailand. Sodium hydroxide $(\mathrm{NaOH})$, sodium carbonate $\left(\mathrm{Na}_{2} \mathrm{CO}_{3}\right)$, sodium silicate $\left(\mathrm{Na}_{2} \mathrm{SiO}_{3}\right)$ and $30 \%$ hydrogen peroxide $\left(\mathrm{H}_{2} \mathrm{O}_{2}\right)$ were laboratory reagents grades.

\section{B. Method}

\section{1) Prewash process}

The knitted fabrics of PLA/cotton blend, 100\% PLA and cotton were boiled in water at $100^{\circ} \mathrm{C}$ for 15 minutes in order to remove the water-soluble impurities before taken to the next process.

\section{2) Scouring process}

The prewashed fabrics were scoured in the processing conditions employing 3 different chemicals viz. sodium hydroxide, sodium carbonate, pectinase enzyme. The condition of scouring is shown in Table 1. The efficiency of these different scouring processes were compared against the blank condition being the process employed only $1 \%$ owf wetting agent at the same temperature and length of the processing time. After scouring, the fabrics were boiled in water at $90^{\circ} \mathrm{C}$ for 15 minutes so as to get rid of the alkali traces $\left(\mathrm{NaOH}\right.$ or $\left.\mathrm{Na}_{2} \mathrm{CO}_{3}\right)$ from the fabrics and to terminate the bioactivity of the pectinase enzyme. The last step was to rinse the fabrics with water and dry at room temperature. The dried fabrics were analyzed their water absorbency using AATCC test method 79-2000 [9].

\section{3) Bleaching processes}

The scoured fabrics were bleached with $30 \% \mathrm{H}_{2} \mathrm{O}_{2}$ at the concentrations of 5 and $7 \%$ owf. Sodium silicate of $2.5 \%$ owf and $0.6 \%$ owf $\mathrm{NaOH}$ were used. The bleaching process was carried out at $100^{\circ} \mathrm{C}$ for 60 minutes, $\mathrm{pH} 10.5-11.0$ and the liquor ratio of $20: 1$. After bleaching, the fabrics were boiled in water at $90^{\circ} \mathrm{C}$ for 15 minutes to eliminate the residual peroxide on the fabrics and later rinsed and dried at room temperature. The whiteness and yellowness of the fabrics were measured according to AATCC Test Method 110-2000 [10].

TABLE I: ThE CONDITIONS OF SCOURING

\begin{tabular}{ccccc}
\hline Chemical & $\begin{array}{c}\text { Concentration } \\
\text { (\%owf })\end{array}$ & $\begin{array}{c}\text { Non- ionic } \\
\text { wetting } \\
\text { agent } \\
(\% \text { owf })\end{array}$ & $\begin{array}{c}\text { Temperature } \\
(\text { (C) }\end{array}$ & $\begin{array}{c}\text { Time } \\
(\mathrm{min})\end{array}$ \\
\hline $\mathrm{NaOH}$ & 3 & 1 & 90 & 60 \\
& 5 & 1 & 70 & 90 \\
$\mathrm{Na}_{2} \mathrm{CO}_{3}$ & 3 & 1 & 90 & 60 \\
& 7 & 1 & 70 & 90 \\
Pectinase* & 10 & 1 & 60 & 60 \\
Blank & - & 1 & 90 & 60 \\
& - & 1 & 70 & 90 \\
\hline
\end{tabular}

* pectinase scouring carried out at $\mathrm{pH} 8-9$

The prewashed fabrics were scoured and bleached in a one-bath, all-in process using hydrogen peroxide solution. The $7 \%$ owf of $30 \% \mathrm{H}_{2} \mathrm{O}_{2}$ was used together with $2.5 \%$ owf sodium silicate, $1 \%$ owf nonionic wetting agent and $0.6 \%$ owf $\mathrm{NaOH}$ at $\mathrm{pH}$ 10.5-11.0 and the liquor ratio of 20:1. The process was performed at $100^{\circ} \mathrm{C}$ for 60 minutes. The fabrics were then boiled in water at $90^{\circ} \mathrm{C}$ for 15 minutes to eliminate the residual peroxide and afterwards the fabrics were rinsed and dried at room temperature. The whiteness and yellowness of the fabrics were measured according to AATCC Test Method 110-2000 [10].

\section{Bursting Strength}

The bursting strength of the fabrics was measured using SDL bursting strength tester Model P1000 followed the JIS L1018 standard method (1999) [11].

\section{RESULTS AND DISCUSSION}

\section{A. Prewash process}

PLA/cotton blended fabric, it was found that water took about 44 seconds to absorb into the fabric as seen in Table 2 . By boiling the blended fabrics at $100^{\circ} \mathrm{C}$ for 15 minutes, the water absorbency properties were slightly improved (water absorption spent about 35 seconds) but still did not pass the standard absorbency (less than 5 seconds is required). The cotton fibers were contaminated with the hydrophobic substances e.g. oils, fats and waxes, which hindered the water absorption into the fabric. The blended fabric exhibited better water absorbency than the $100 \%$ cotton fabric as it contained only $50 \%$ wt cotton. However, the pretreatment process is still needed for the blend because its water absorbency was still 
lower than the standard level. PLA is a synthetic fiber on which the processing lubricants are present as an impurity. Once it was boiled in a $1 \%$ owf nonionic wetting agent at $70^{\circ} \mathrm{C}$ for 15 minutes, the PLA fabric could readily absorb water and the fabric whiteness was higher than 72 , so it was ready to enter the dyeing process. Cotton as the most widely used fabric already has its appropriate scouring and bleaching conditions, so this work focused only on the investigation of those conditions for the blended fabric. In addition, the prewash process could improve the fabric strength because of the stress relaxation occurred during washing resulting in the shrinkage of the fabrics.

TABLE II: THE PROPERTIES OF THE GREIGE AND THE PREWASHED PLA/COTTON BLENDED FABRICS COMPARING WITH 100\% PLA AND COTTON FABRICS

\begin{tabular}{llccc}
\hline Fabrics & Process & Absorbency (s) & Whiteness & Strength (KPa) \\
\hline \multirow{2}{*}{ Cotton } & Greige & $60+$ & -4.671 & $859.0 \pm 31.1$ \\
& Prewashed & $60+$ & 9.937 & $935.8 \pm 25.2$ \\
\multirow{2}{*}{ Blend PLA/Cotton } & Greige & $44.18 \pm 3.74$ & 19.175 & $649.2 \pm 21.6$ \\
& Prewashed & $34.76 \pm 3.15$ & 28.180 & $749.4 \pm 27.0$ \\
\multirow{2}{*}{ PLA } & Greige & $60+$ & 76.091 & $622.0 \pm 25.8$ \\
& Prewashed* & adequate & 79.570 & $726.0 \pm 30.3$ \\
\hline
\end{tabular}

$*$ PLA was prewashed with $1 \%$ owf nonionic wetting agent, L.R. $20: 1$ at $70^{\circ} \mathrm{C} 15$ minutes

\section{B. Scouring Process}

When the prewashed PLA/cotton blended fabric was taken to study scouring with $\mathrm{NaOH}, \mathrm{Na}_{2} \mathrm{CO}_{3}$ and pectinase enzyme at various conditions, the water absorbency, the whiteness and the strength of the fabrics were determined in comparison with the prewashed fabrics with wetting agent as shown in Table 3. The chemicals used in the conditions shown in Table 3 were at their minimum amount that could provide a standard water absorbency to the fabric. The fabric prewashed with only wetting agent could not absorb water well due to the lack of alkali to saponify oils and fats on the cotton fiber into water-soluble fatty acid and triglyceride [4]. By scouring with $\mathrm{NaOH}, \mathrm{Na}_{2} \mathrm{CO}_{3}$ and pectinase, the alkalinity was involved in the process, therefore, a better water absorbency of the fabrics was obtained. However, the amount of alkali used should compromise with the strength of the PLA fiber because PLA could be damaged by alkali. From the experiment, it exhibited that using a low-concentration $\mathrm{NaOH}$ at an elevated scouring temperature (3\% owf $\mathrm{NaOH}, 90^{\circ} \mathrm{C}, 60 \mathrm{~min}$ ) could impair the fabric strength even more severely than the scouring at low temperature with high $\mathrm{NaOH}$ concentration $(5 \%$ owf $\mathrm{NaOH}$, $\left.70^{\circ} \mathrm{C}, 90 \mathrm{~min}\right)$. In the mean time, the fabric strength was independent of the scouring temperature in the case of scouring with $\mathrm{Na}_{2} \mathrm{CO}_{3}$ due to a lower alkalinity, thereby causing less hydrolysis on the PLA structure, as a result, fabric strength reduced to a less extent than the $\mathrm{NaOH}$ case. Scouring by pectinase enzyme also improved the water absorbency of the blended fabrics because pectinase eliminated the pectic substance on the cotton fiber resulting in a removal of hydrophobic substances [12]. Furthermore, the use of pectinase did not affect the strength of the blended fabric as it did not destroy the PLA structure.

The whiteness values of the scoured fabrics are shown in Table 3. Not only removing the polar fat compounds, the alkaline solution also eliminated the color matters on the cotton fiber. The alkaline solution and the elevated temperature caused fiber swelling and the impurities were then easily removed, therefore, the scouring with $\mathrm{NaOH}$ provided a higher degree of whiteness to the blended fabric than the other scouring agents studied. From the fabric strength in Table 3, the optimum scouring conditions which exhibited the least effect on the fabric strength for 3 different scouring chemicals, was selected. The suitable scouring condition for each scouring agents were $5 \%$ owf $\mathrm{NaOH}\left(70^{\circ} \mathrm{C}\right.$, $90 \mathrm{~min}), 7 \%$ owf $\mathrm{Na}_{2} \mathrm{CO}_{3}\left(70^{\circ} \mathrm{C}, 90 \mathrm{~min}\right)$ and $10 \%$ owf pectinase $\left(60^{\circ} \mathrm{C}, 60 \mathrm{~min}\right)$. The results are depicted in Table 4. These scouring conditions could be used as a pretreatment process for the blended fabrics which will go through deep-shade dyeing, however, if a pale shade is demanded, these scoured fabric is still required bleaching in order to achieve a right shade on the fabrics in the dyeing process.

\section{Bleaching process}

The majority of the colorants were removed by the $\mathrm{H}_{2} \mathrm{O}_{2}$ bleaching which was the process to oxidize the molecules of the natural colorants on the cotton fabric into colorless substances. The amount of $\mathrm{H}_{2} \mathrm{O}_{2}$ used to whiten the fabric in the bleaching process was varied depending on the whiteness of the starting fabrics. In Table 4, scouring with 5\%owf $\mathrm{NaOH}$ required only 5\%owf $\mathrm{H}_{2} \mathrm{O}_{2}$ in bleaching because such concentration sufficiently provided whiteness to the fabric (standard whiteness is 72). The fabrics scoured with $\mathrm{Na}_{2} \mathrm{CO}_{3}$ and pectinase and the prewashed ones needed $7 \%$ owf $\mathrm{H}_{2} \mathrm{O}_{2}$ for bleaching in order to achieve a standard whiteness. Besides, the scouring and bleaching could also be done altogether in one step because the obtained blended PLA/cotton fabrics could readily absorb water and the fabric whiteness was in the standard level. The fabric pretreated in the one-bath scouring/bleaching process still maintained the strength level similar to the scouring with pectinase followed by $\mathrm{H}_{2} \mathrm{O}_{2}$ bleaching and higher than the scouring with the alkaline solution $\left(\mathrm{NaOH}\right.$ and $\mathrm{Na}_{2} \mathrm{CO}_{3}$ ) followed by $\mathrm{H}_{2} \mathrm{O}_{2}$ bleaching.

The results in the strength of the pretreated fabrics compared with the prewashed ones (Fig. 2.) illustrated that the scouring process influenced on the strength of the blended fabrics more than the bleaching process. It can be explained as a result of a stronger alkaline condition of the scouring process directly affected the structure of PLA. The blended fabric then exhibited a significantly lower strength comparing with the other processes. However, pretreatment of the PLA/cotton blended fabric for pale-shade dyeing should be the one-bath scouring/bleaching process with $\mathrm{H}_{2} \mathrm{O}_{2}$ because the fabric strength was still maintained in a high level and at the same time, it was a time- and chemical-saving process. 
TABLE III: PROPERTIES OF THE PLA/COTTON BLENDED FABRIC AFTER BEING SUBJECTED TO DIFFERENT SCOURING CONDITIONS.

\begin{tabular}{ccccc}
\hline Chemical scouring & conditions & Absorbency (s) & Whiteness & Strength (KPa) \\
\hline $\mathrm{NaOH}$ & $3 \%$ owf, $90^{\circ} \mathrm{C}, 60 \mathrm{~min}$ & adequate & 41.868 & $670.8 \pm 9.96$ \\
& $5 \%$ owf, $70^{\circ} \mathrm{C}, 90 \mathrm{~min}$ & adequate & 37.863 & $711.2 \pm 17.34$ \\
$\mathrm{Na}_{2} \mathrm{CO}_{3}$ & $3 \%$ owf, $90^{\circ} \mathrm{C}, 60 \mathrm{~min}$ & $0.88 \pm 0.16$ & 38.772 & $730.8 \pm 11.13$ \\
& $7 \%$ owf, $70^{\circ} \mathrm{C}, 90 \mathrm{~min}$ & adequate & 33.178 & $733.4 \pm 21.6$ \\
Pectinase & $10 \%$ owf, $60^{\circ} \mathrm{C}, 60 \mathrm{~min}$ & $0.96 \pm 0.17$ & 28.269 & $744.4 \pm 28.18$ \\
Wetting agent & $1 \%$ owf $70^{\circ} \mathrm{C}, 90 \mathrm{~min}$ & $9.15 \pm 1.09$ & - & $740.0 \pm 24.42$ \\
& $1 \%$ owf, $90^{\circ} \mathrm{C}, 60 \mathrm{~min}$ & $7.98 \pm 1.14$ & & $733.0 \pm 13.55$ \\
\hline
\end{tabular}

TABLE IV: PROPERTIES OF THE PLA/COTTON BLENDED FABRICS AFTER BLEACHING.

\begin{tabular}{|c|c|c|c|c|c|c|c|}
\hline \multirow{2}{*}{$\begin{array}{c}\text { Blend } \\
\text { PLA/cotton }\end{array}$} & \multirow{2}{*}{$\mathrm{H}_{2} \mathrm{O}_{2}$} & \multicolumn{2}{|c|}{ Scoured conditions } & \multirow{2}{*}{ Absorbency (s) } & \multirow{2}{*}{ Whiteness } & \multirow{2}{*}{ Yellowness } & \multirow{2}{*}{ Strength $(\mathrm{KPa})$} \\
\hline & & Chemicals & Temp, time & & & & \\
\hline Greige & & & & 44.18 & 19.175 & 20.76 & $649.2 \pm 21.6$ \\
\hline Prewashed* & & & & 34.76 & 28.180 & 17.88 & $749.4 \pm 27.0$ \\
\hline \multirow[t]{3}{*}{ Two-Step ${ }^{a}$} & $5 \%$ owf & $\mathrm{NaOH}: 5 \%$ owf & $70^{\circ} \mathrm{C}, 90 \mathrm{~min}$ & adequate & 74.665 & 3.467 & $693.5 \pm 16.7$ \\
\hline & $\begin{array}{l}5 \% \text { owf } \\
7 \% \text { owf }\end{array}$ & $\mathrm{Na}_{2} \mathrm{CO}_{3}: 7 \%$ owf & $70^{\circ} \mathrm{C}, 90 \mathrm{~min}$ & adequate & $\begin{array}{l}67.539 \\
72.087\end{array}$ & $\begin{array}{l}5.769 \\
4.316\end{array}$ & $720.0 \pm 21.3$ \\
\hline & $\begin{array}{l}5 \% \text { owf } \\
7 \% \text { owf }\end{array}$ & Pectinase : $10 \%$ owf & $60^{\circ} \mathrm{C}, 60 \mathrm{~min}$ & adequate & $\begin{array}{l}67.767 \\
72.666\end{array}$ & $\begin{array}{l}5.906 \\
4.517\end{array}$ & $731.0 \pm 8.3$ \\
\hline One-Step ${ }^{\mathrm{b}}$ & $7 \%$ owf & - & & adequate & 72.469 & 4.010 & $728.7 \pm 8.4$ \\
\hline
\end{tabular}

* Prewashed fabric was boiled at $100^{\circ} \mathrm{C} 15$ minutes

${ }^{a}$ Initial fabric was scoured fabric, and ${ }^{\mathrm{b}}$ initial fabric was prewashed fabric.

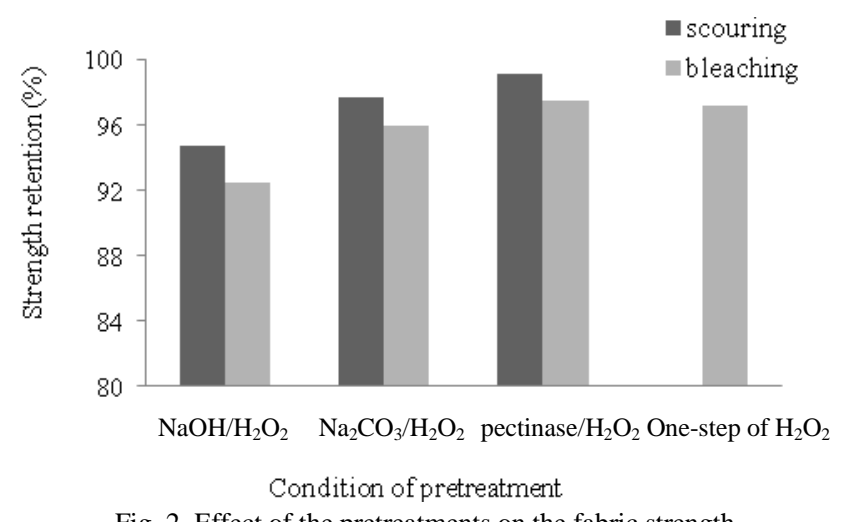

Fig. 2. Effect of the pretreatments on the fabric strength.

\section{CONCLUSION}

As the PLA fiber is rather thermally and alkali sensitive, the pretreatment processes used for the PLA/cotton blended fabric should be carefully controlled. In our research, the chemical used had the effect on the PLA structure and the temperature higher than $70^{\circ} \mathrm{C}$ was not recommended. In order to avoid such problem, pretreating the fabric with enzyme is the most appropriate option. Selection of the right enzyme corresponding to the types of impurities present on the fibers would promote a better scouring efficacy while the fabric strength is maintained. In addition, pretreatment with enzyme is also eco-friendly.

\section{ACKNOWLEDGMENT}

The authors are indebted to National Innovation Agency (NIA) for their support on the research project C53-53. A part of this research was funded by the Center of Advanced Studies for Agriculture and Food, KU Institute for Advanced Studies, Kasetsart University, Bangkok 10900, Thailand.

\section{REFERENCES}

[1] A. Angehardt, "The fiber year 2009/10 A World Survey on Textile and Non-Woven Industry," Oerlikon Textiles GmbH \& Co.KG., Germany, issue 10, May 2010

[2] B. Guptaa, N. Revagadea, and J. Hilbornb, "Poly(lactic acid) fiber: An overview," Progress in Polymer Science., vol. 32, pp. 455-482, 2007.

[3] J. R. Dorgan, H. Lehermerier, and H. Mang, "Thermal and rheological properties of commercial-grade poly(lactic acid)," Journal of Polymers and the Environment., vol. 8, pp. 1-9, 2000.

[4] J. A. Cicero, J. R. Dorgan, J. Garrett, and J. S. Lin, "Effect of molecular architecture on two-step, melt-spun poly(lactic acid) fibers," Journal of Applied Polymer Science., vol. 86, pp. 2839-2846, 2002.

[5] J. Suesat, D. Phillips, M. Wilding, and D. Farrington, "The influence of yarn-processing parameters on the tensile properties and structure of poly (1-lactic acid) fibres," Polymer., 44(19), 2003. 5993-6002

[6] J. Suesat1, P. Sae-be, and P. Suwanruji, "Effect of Pretreatment and Dyeing Processes on the Physical Properties of Poly (Lactic Acid)/Cotton Blended Fabric," Advanced Research Materials., vol. 486, pp. 253-259, 2012

[7] S. Karmakar, "R. Textile science and technology," volume 12: Chemical technology in the pre-treatment processes of textiles. Elsevier Science B.V. ,1999.

[8] P. Sae-be, U. Sangwatanaroj, and H. Punnapayak, "Analysis of the products from enzymatic scouring of cotton," Biotechnology Journal., vol. 2, pp. 316-325, 2007.

[9] AATCC test method 79-2000, Absorbency of bleached Textiles.

[10] AATCC Test Method 110-2000, Whiteness of Textiles.

[11] JIS L1018-1990, Testing Methods for Knitted Fabrics.

[12] Y. Li and I. R. Hardin. "Enzymatic Scouring of Cotton: Effect on Structure and Properties," Textile Chemist and Colorist., vol. 29, no. 8, pp. 71-76, 1997. 